\title{
味覚センサを応用した出張理科教室による 高校生の理科教育への取り組み
}

Approach to Science Education of High School Students by a Delivery Science Class Applying Taste Sensor

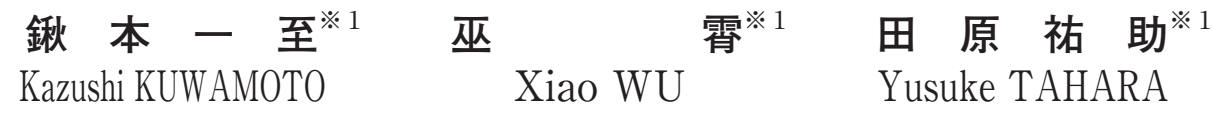

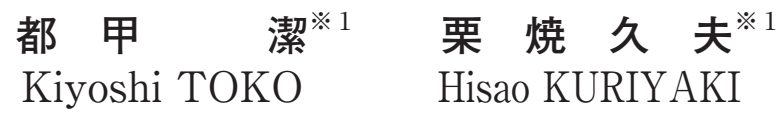

1.はじめに

経済協力開発機構 (Organisation for Economic $\mathrm{Co}^{-}$ operation and Development: OECD）が実施した2006 年度の生徒の学習到達度調査 (Programme for International Student Assessment：PISA）において，日 本の高校 1 年生は, 科学的リテラシー分野で 57 カ国中、 第 6 位の得点をあげている ${ }^{11}$. ここで, 日本よりも統 計的に有意に高い得点をあげた国はフィンランドのみ であったことから，日本の生徒は国際的に高い学力水 準を有するといえる。一方で，同年のアンケートにお いて「私は自分の役に立つとわかっているので，理科 を勉強している」,「私は理科の科目からたくさんのこ とを学んで就職に役立てたい」という2つの質問に対 して，「そうだと思う」「全くそうだと思う」と回答し た生徒の割合は, ともに国際平均を 20 ポイント近く下 回った ${ }^{1)}$. 以上を踏まえると, 日本の生徒は国際的に 高い理科学力を有しているにもかかわらず，理科を学 ぶ意義や有用性に関しては実感していないといえる.

文部科学省では，このような現状を「理科離れ」と 命名し, 本問題の改善に向けて, スーパーサイエンス ハイスクール $(\mathrm{SSH})$, 未来の科学者養成講座, サイエ ンス・パートナーシップ・プロジェクト $(\mathrm{SPP})$ 等の 理科教育事業を推進している ${ }^{2)}$ 。これらの事業は, 科 学実験を通して「理科は楽しい」と生徒に実感させる ことで, 将来的に科学者を志す生徒の拡大を目指して いる.このとき,生徒の理科への関心を高めるために, 「理科は楽しい」という感情を抱かせることは確かに重 要である.しかしながら, PISA2006のアンケートを考 慮すると，生徒の理科離れの原因は，理科への関心の 低さだけではなく，理科を学ぶ意義や有用性を実感で きていない点にも起因すると考える. 従って, 理科教

2014 年 3 月 29 日受付

※ 1 九州大学
育事業の科学実験では, 生徒の関心を引きやすく, な おかつ, 理科を学ぶ意義や有用性を実感できる題材を 取り扱うことが重要である。本研究では, 人間の味覚 を再現する味覚センサが, 高校の履修科目である「生 物」「物理」「化学」と関連した特徽を持ち, さらに, 食品業界や医薬品業界で応用されている先端技術であ ることから, 理科教育への応用性を期待して科学実験 の題材として取り上げた。

味覚センサは, 脂質高分子膜を貼付した作用電極と 参照電極から構成される 2 電極系の機構を有してお り, 作用電極の膜電位を測定することで食品の味を数 值化している ${ }^{3), 4)}$. ここで, 作用電極で使用する脂質 高分子膜の組成を調整することで, 基本味（塩味, 酸 味，うま味，苦味，甘味）および渋味の各味に対して 選択的に応答するセンサ特性を実現している ${ }^{3), 4)}$. 現 在, 味覚センサを搭載した味認識装置が, (株インテリ ジェントセンサーテクノロジーから市販されている. 味覚センサの測定原理は, 水溶液中で帯電する脂質高 分子膜とイオン化した呈味物質間にはたらく静電的あ るいは物理的な相互作用に起因した膜電位の変化に基 づいている5 ${ }^{5}$.

味覚センサの特徵である生体模倣や測定原理は, 高 校の履修科目である「生物」「物理」「化学」と以下の 点で関連している。

（1）生物：人間の味覚を数值化する,

(2) 物理 : 2 本の電極間の電圧を測定する,

（3）化学：イオンとの相互作用を利用する

従って, 我々は味覚センサを応用した理科教材が, 生 徒に座学と先端技術との繋がりを把握させ, 理科を学 ぶ意義と有用性を実感させる良い教材になると期待し ている. 現在, 筆者らは, 中高生の理科への学習意欲 を向上させるために理科教材としての味覚センサ（以 降, 教育用味覚センサと呼称する) の開発を行ってい る $^{6)}$. 本稿では, 高校生の理科教育への取り組みとし 
て, 教育用味覚センサを大阪市立東高等学校での出張 理科教室に導入した成果について報告する。ここで, 出張理科教室とは, 生徒の理科離れを改善するために, 大学や企業が中学校や高校に出向いて科学実験などを 実施する授業を指している.

\section{2. 出張理科教室の内容}

平成 25 年 7 月 11 日に大阪市立東高等学校で出張理科 教室を実施した。本理科教室は, 1 時間半の開催で, 普 通科理数コースおよび理数科に在籍する高校 2 年生 36 名（男子 12 名，女子 24 名）が参加した。このとき, 理 科教室の参加者は，東高校の教員が授業やポスターで 理科教室の内容を生徒に告知することで募集した，当 日は, 我々の研究室の教員 2 名およびTA（Teaching Assistant） 5 名で害施した。次節より, 本理科教室の 実施内容をタイムスケジュールに沿って記述する。

2.1 大学紹介および市販飲料を用いた実験

理科教室の冒頭では, 九州大学電気情報工学科およ び我々の研究室について紹介した，その後, 生徒の関 心を引くために, 市販飲料を用いた簡単な実験を行っ た. 実験では, 牛乳, 麦茶および砂糖を混ぜ合わせて, 希望する生徒に試飲させた（この混合液はコーヒー牛 乳と似た味を呈する)。当日は，ほとんどの生徒が本 実験に参加した，次に，生徒に味覚センサの有用性を 認識させるために, 上記の混合液と市販のコーヒー牛 乳の味が似ていることを味覚センサの測定結果で示し た. 最後に, 履修科目との繋がりを実感させるために, 味覚センサの測定原理とその応用分野についてパワー ポイントを用いて説明した。

\section{2 教育用味覚センサを用いた実験}

本実験では，生徒は 7 名あるいは 8 名の班に分かれ た（全 5 班）。ここで, 各班には TAが 1 名ずつ就き, 班の進行状況に応じてサポートを行った。 また, 教員 2 名は教室全体のサポートを担当した。次項より, 本 実験の詳細について記述する。

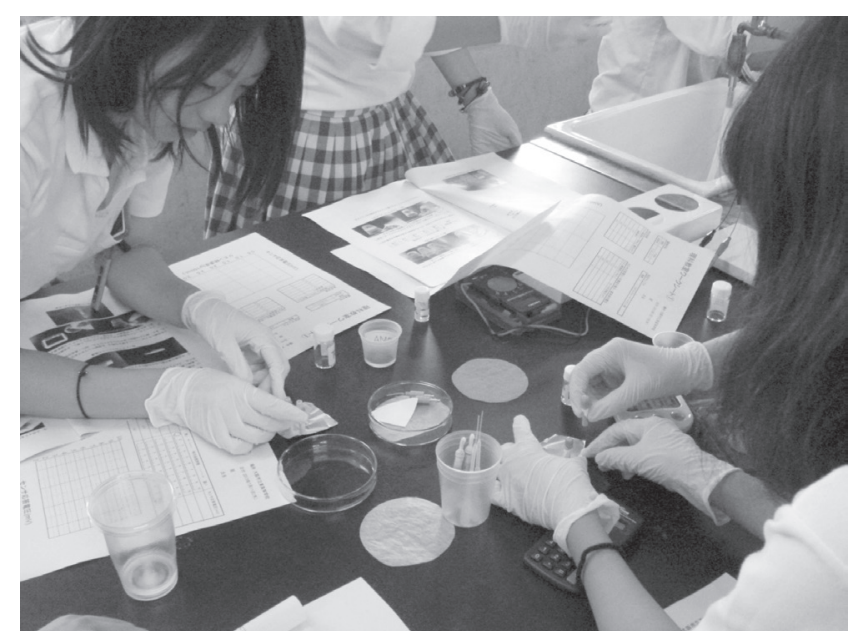

図 1 教育用味覚センサ作製の様子

\section{（1）センサ材料}

教育用味覚センサの脂質には, 市販の味覚センサ 電極で用いられている TOMA (trioctylmethylammonium chloride, 東京化成工業(侏) およびPAEE（phosphoric acid di (2-ethylhexyl) ester, 東京化成工業 (株) を使用した。また，脂質を含浸させる支持膜とし てテフロン膜（ポアサイズ $0.1 \mu \mathrm{m}$, 東洋滤紙(株)), 中空 棒としてポリ塩化ビニル素材のものを使用した。ここ で, TOMAおよびPAEEを採用した理由は, 第一に, 市販の味覚センサの脂質高分子膜で使用されているこ と, 第二に, 水溶液中でそれぞれ正と負に帯電するこ とで, 静電相互作用を利用した酸味への応答が可能で あること, 第三に, 常温で液体であり, 脂質溶液の希 釈に用いるエタノールに溶けやすい性質を有すること に基づいている.

（2）教育用味覚センサの作製

センサを作製する生徒は各班 4 名とし, 希望者によ る挙手で担当者を決定した。また，希望者がいない場 合は，TAが座席位置などを考慮して担当者 4 名を指 名した，担当する生徒は，以下の作製手順㧍よびTAの 指示に従い, 1 人 2 本ずつセンサを作製した (図 1 ).

（a）テフロン膜を中空棒の先端に被せて輪ゴムで固 定する.

（b）テフロン膜を脂質溶液に 30 秒間浸す，その後， 10分間乾燥させる.

（c）中空棒の内部に $3.3 \mathrm{M} \mathrm{KCl}$ 充填し, 銀塩化銀 電極を取り付ける.

完成した教育用味覚センサを図 2 に示す.このとき, 脂質溶液には, TOMAあるいはPAEEをエタノールで 希釈したものを用いた。

（3）測定サンプルの調製

センサ作製を担当しない生徒は, 市販のクエン酸と

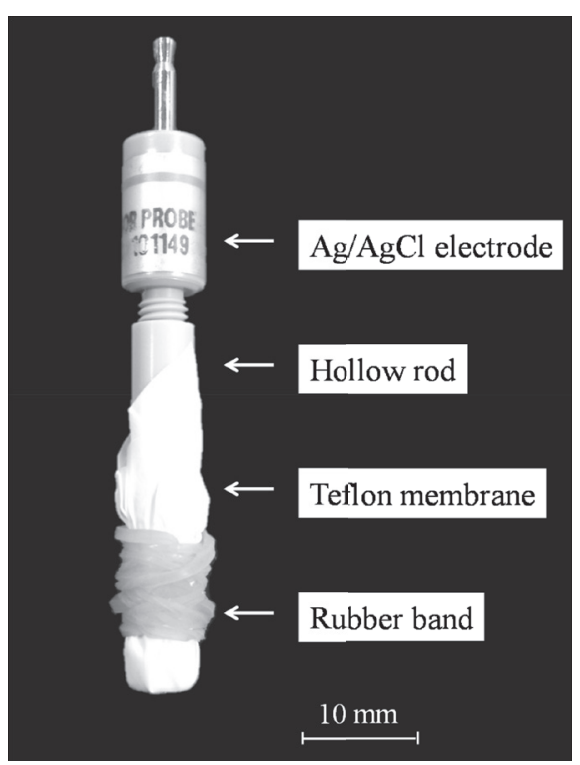

図 2 作製した教育用味覚センサ 


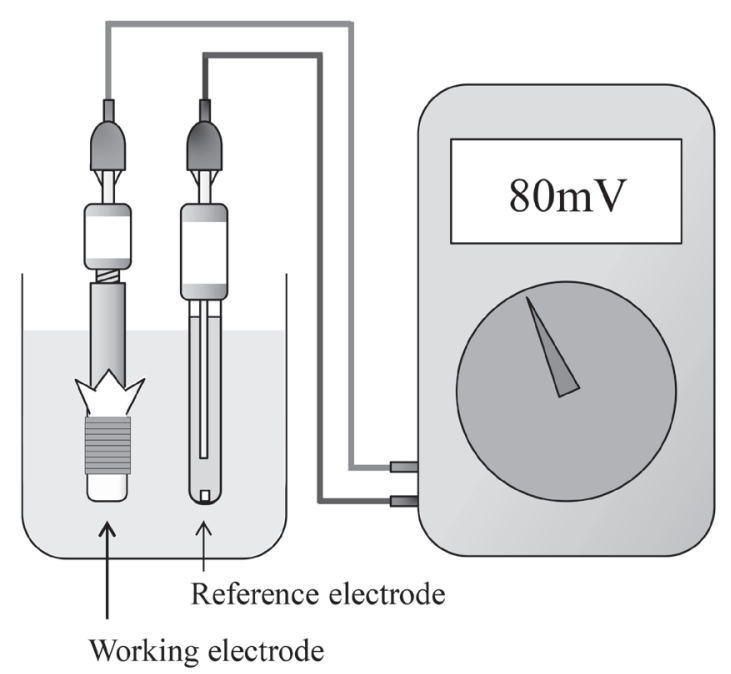

図 3 実験機構

ミネラルウォーターを用いて，測定実験で使用するサ ンプルを調製した。 カップに投入するクエン酸スティ ックの本数を調整することで 5 濃度のクエン酸サンプ ル $(1.0,1.5,2.0,2.5,3.0 \mathrm{~g} / 150 \mathrm{~mL})$ を用意した。

(4) 実験機構および測定手順

市販の味覚センサの測定手法と同様に, 作用電極と 参照電極から構成される 2 電極系の測定機構を採用し た.このとき，教育用味覚センサを作用電極，銀塩化 銀電極を参照電極として使用し，両電極をそれぞれ電 圧計に接続した(図 3 )。生徒は以下の手順でサンプル を測定した。

（a）作用電極および参照電極を洗浄液ですすぐ.

（b）両電極を基準液に浸し， 1 分後に電圧（Vr) を 測定する。

（c）作用電極および参照電極を洗浄液ですすぐ.

(d) 両電極をサンプルに浸し， 1 分後に電圧 $(V \mathrm{~s})$ を測定する.

以上が測定の 1 サイクルである。実験では， 5 種類 のクエン酸サンプルで 1 サイクルずつ繰り返した。こ こで, サンプルで測定された電圧（ $V \mathrm{~s} ）$ から基準液で 測定された電圧（Vr) を引いたものをセンサ応答電圧 $(V \mathrm{~s}-V \mathrm{r})$ と定義した。 また，基準液掞よび洗浄液に はミネラルウォーターを使用している。

（5）実験結果

実験が成功すると, センサ応答電圧がサンプル濃度 の対数に比例したグラフが得られる. 本理科教室では, 半数の班で期待通りの結果が示された。ここで, 実験 が失敗した要因には，中空棒にスポイトを用いて内部 液を注入する際に，生徒が不慣れであるために気泡が 混入したことが考えられる。

（6）官能検查

官能検査では，測定実験で用いた 5 濃度のクエン酸 サンプルのうち, 人間が味の違いを区別できる最小幅 の1.2 倍 ${ }^{3)}$ に近い濃度差である 4 濃度のサンプル (1.5,

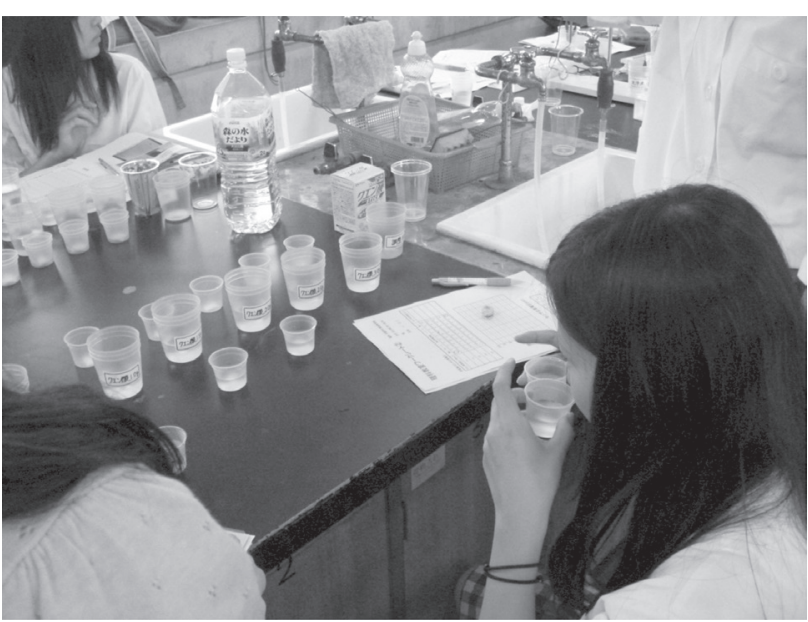

図 4 官能検査の様子

2.0，2.5，3.0 g/150mL）を使用した。試飲者は，ラン ダムに並び替えられた 4 つのサンプルを試飲し, 左か ら濃度が薄いと感じた順番に並び替えた(図 4)。本実 験では, サンプル濃度を人間が味を区別できる限界值 付近に設定しているため, 1 回目の正答率が 3 割程度 に止まった，このとき，サンプルの並び替えが正解す るまで何度も挑戦する生徒が見受けられた。

\section{3. 出張理科教室の評価}

今回の出張理科教室を評価するために, 参加した生 徒36名に対して無記名式のアンケートを実施した。本 アンケートでは，それぞれの質問に対して5段階（強 くそう思う，そう思う，どちらでもない，そう思わな い, 全くそう思わない）から自身の回答に最も近い選 択肢を選ぶ形式を採用した。 また，各設問には，回答 した理由を記述するための空闌を設けた。アンケート の設問とその結果を図 5 に示す，本アンケートは，理 科教室への参加者 36 名のうち, 提出がなかった 1 名を 除いた35名から回答を得た。

設問 1 は, PISAのアンケート結果を意識したもの で, 今回, 肯定の「強くそう思う」「そう思う」と回答 した生徒の割合は68 \%となり, PISA2006の類似した 設問の平均值 $42 \%{ }^{1)}$ と比較して高い数值を示した。 こ れら 2 つのアンートでは, 対象学年や母集団等が異 なるため, 本結果が生じた要因を特定することは難し いが, その理由の 1 つして, 本理科教室において希 望者が参加する形式を採用したことが考えられる. 設 問 2 では, 肯定の「強くそう思う」「そう思う」と回答 した生徒の割合は $97 \%$ に達したことから, ほとんどの 生徒が, 本理科教室が座学の応用分野を知る良い機会 になったと感じていることが読み取れる。ここで，本 設問の回答理由には,「実験器具など普段触れない物 に触れることができた」「大学で行われていることを 知ることができたので, 進路を決める上で参考になっ た」などの意見がみられた。設問 3 では, 肯定の「強 


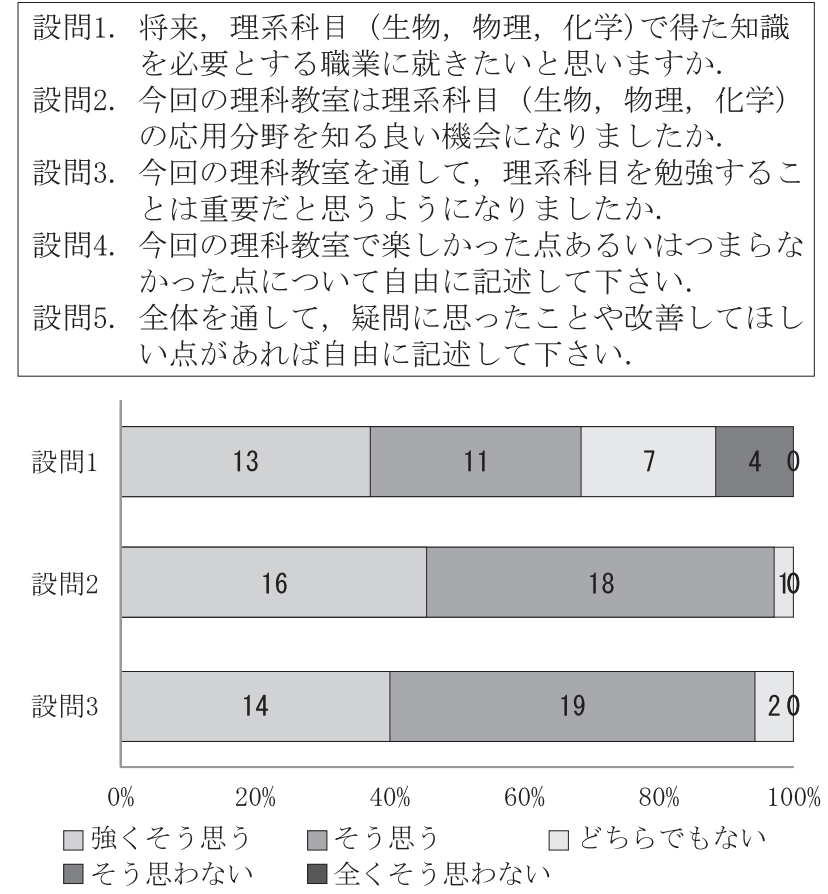

図 5 生徒向けアンケート結果
設問1. 今回の理科教室では，生徒がよく質問していたと 思いますか。

設問2．今回の理科教室では，生徒の質問に対して適切に 回答できましたか.

設問3．理科教室で行った実験は，停滞なくスムーズに進 めることができましたか.

設問4. 理科教室中の雾囲気は良かったですか.

設問5. 今回の理科教室で感じた良い点と悪い点について 自由に記述して下さい.

設問6. 全体を通して，疑問に思ったことや改善してほし い点があれば自由に記述して下さい.

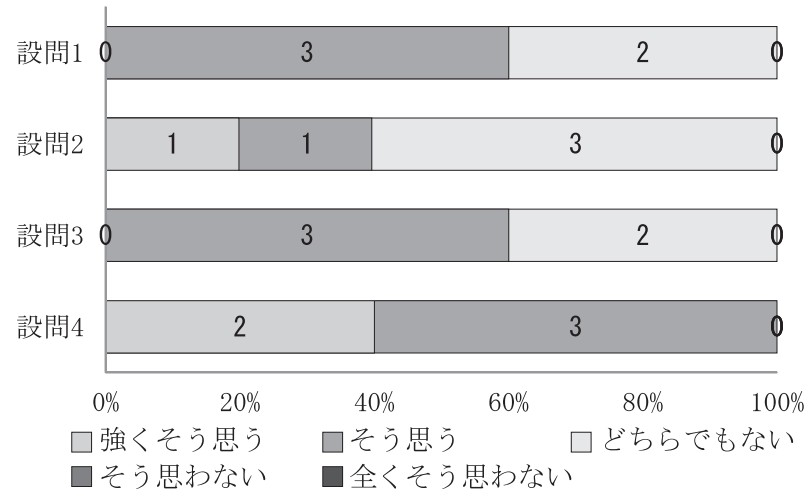

図 6 TA向けアンケート結果

に, サポーターとして参加したTA 5 名に対して記名 式のアンケートを実施した，TA向けのアンケートで は，生徒向けのアンケートと同様の形式を採用した， アンケートの設問とその結果を図 6 に示す.

設問 1 では,「強くそう思う」と回答したTAはいな かったものの, 否定的な回答は示されなかった。この とき, 本設問の回答理由では, 「生徒が実験内容や進路 などについて積極的に質問してきた」という意見が大 半を占めていた。 従って, 今回の理科教室では, 生徒 が積極的に参加できていたと思われる。設問 2 では， TAから否定的な回答は示されなかったものの, 回答 理由に打いて,「普段, 教育用味覚センサの開発に携 わっていないので回答できない質問があった」「専門 の分野ではないので, 脂質の電荷の符号を答える際に 戸惑った」などの意見がみられた，従って，TAに向 けた理科教室前のゼミが不十分であったことが示され た。設問 3 では, 前設問と同様にTAから肯定的な回 答が得られたが, その理由において,「実験のなかで失 敗しやすい部分があった」「TA 同士で実験の要点を共 有し，実験がよりスムーズに進むように努めたい」な どの意見がみられた。設問 4 では, TA 全員から肯定 的な評価を得ることができた，回答理由としては,「市 販飲料を用いた実験や，クエン酸を使った濃度当て実 験で盛り上がった」という意見が多くみられた，設問 5 では, 理科教室の良い点として, 初めての理科教室 であったが道具の不足がなかったことや，プレゼンテ ーションを使って生徒の興味を引きやすくしていたこ とが挙げられた。 また, 悪い点としては, 冒頭の大学 等の説明が長かったことや, 楽しむ実験と真面目に取

\section{4. 問題点の分析と改善策の検討}

\section{1 問題点の分析}

今回の出張理科教室における問題点を分析するため 
り組む実験のメリハリが無かったなどの意見がみられ た. 設問 6 では, TAの人数に比べて生徒の人数が多す ぎたことや，理科教室前の TAの予行練習の回数が少 なかったことなどが挙げられた，また，理科教室の内 容ではないが,「当日，会場まで運ぶ器材が多かった」 という意見もみられた。

\section{2 改善策の検討}

生徒およびTA向けのアンケートで挙げられた本理 科教室の問題点を以下にまとめる.

(1) 冒頭の説明が長い.

（2）実験で失敗しやすい部分がある。

（3）TAに向けた理科教室前のゼミが不十分である.

（4）楽しむ実験と真面目に行う実験のメリハリがつい ていない.

今回の理科教室では, 冒頭の説明に25分を費やし, 当初の予定である 20 分をわずかに超過した.このとき， 説明の内容には過不足は無かったが，理科教室全体の 90分における比重が大きいため, 研究室の紹介と市販 飲料を用いた実験を並行することで時間の短縮を図り たい，実験内容に関しては，スポイトを使って中空棒 に内部液を注入する際に気泡が混じってしまう問題が あった，改善策として，中空棒を半透明の材料に変更 し，気泡が混じったことを容易に確認できる状態にす ることで本問題に対処したいと考えている. 今回, 理 科教室前のゼミは，全体を通したリハーサル程度の内 容であったため，今後は，ゼミの回数を増やし，教育 用味覚センサへの理解を深めることで, TAとして参 加する学生に理科教室の内容を熟知させたい. 本理科 教室の実験では，生徒が盛り上がり過ぎて収拾がつか なくなる場面があったので，生徒の関心を引くような 実験は，メリハリをつけるために理科教室の冒頭ある いは最後にまとめて実施するなどタイムスケジュール を工夫したいと考えている.

今回の理科教室は, 開催時間が 1 時間半と短時間で あり，実施内容を取捨選択する必要があったが，今後 はより長い時間の理科教室を検討しているので，ここ で寄せられた意見を参考に，今後の理科教室の内容を 取り決めたい。

\section{5. まとめ}

本研究では, 高校生の理科教育への取り組みとして, 味覚センサを導入した出張理科教室を行い, その教育 効果を検討した．理科教室では，簡易的な味覚センサ を用いた実験を通して，生徒に座学と先端技術との繋 がりを認識させ, 理科を学ぶ意義と有用性を実感させ るように努めた，実施したアンケートより，本理科教 室が，高校生にとって履修科目の応用分野にふれる良 い機会となり, 生徒に理科を勉強することの重要性を
認識させるのに効果的であることが示された.

味覚センサを用いた理科教室は, 初の試みであった ため, アンケートの意見を参考にして, 理科教室の内 容をより充実させたいと考えている. 今後とも, 高校 生の理科教育の一環として, 本取り組みを継続できれ ば幸いである。

\section{謝辞}

本研究は, JSPS科研費25560082の助成を受けた。ま た, 出張理科教室の実施に際しては大阪市立東高等学 校の西山惠美先生よりご協力を頂きました．ここに， 心よりお礼を申し上げます。

\section{参 考 文 献}

1 ）小倉 康: 国際比較から見た日本の生徒にとって の理科学習, 応用物理, $81-10, p p .845-849,2012$

2 ) 文部科学省 : 初等中等教育段階における科学技 術人材育成支援, Webページ, http://www.mext. go.jp/a_menu/jinzai/gakkou/1309813.htm, 2013, 参照日：2013-11-13

3 ) Y. Kobayashi, M. Habara, H. Ikezaki, R. Chen, Y. Naito, and K. Toko: Advanced Taste Sensors Based on Artificial Lipids with Global Selectivity to Basic Taste Qualities and High Correlation to Sensory Scores, Sensors, 10-4, pp.3411-3443, 2010

4) Y. Tahara and K. Toko : Electronic Tongues-A Review, IEEE Sensors Journal, 13-8, pp.3001 3011, 2013

5 ) M. Habara and K. Toko: Biomimetic Membrane for Taste Sensing, Bottom-Up Nanofabrication, 6, $91-109,2009$

6 ) 荒瀬仁志, 安浦雅人, 田原祐助, 小野寺武, 栗焼久 夫, 都甲 潔 : 教育用味覚センサキットの試作, 電 気学会研究会資料. CHS, ケミカルセンサ研究会, pp. $21-24,2012$

\section{著 者 紹 介}

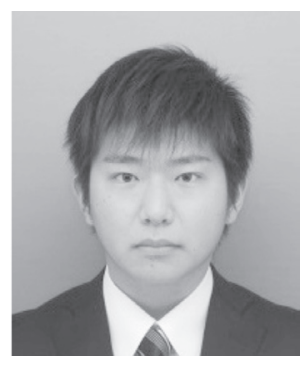

鍬本一至

2012年3月熊本高等専門学校専攻科電子情 報システム工学専攻修了. 同年 4 月九州大 学大学院システム情報科学府修士課程進 学. 現在に至る. 電気学会学生員. 